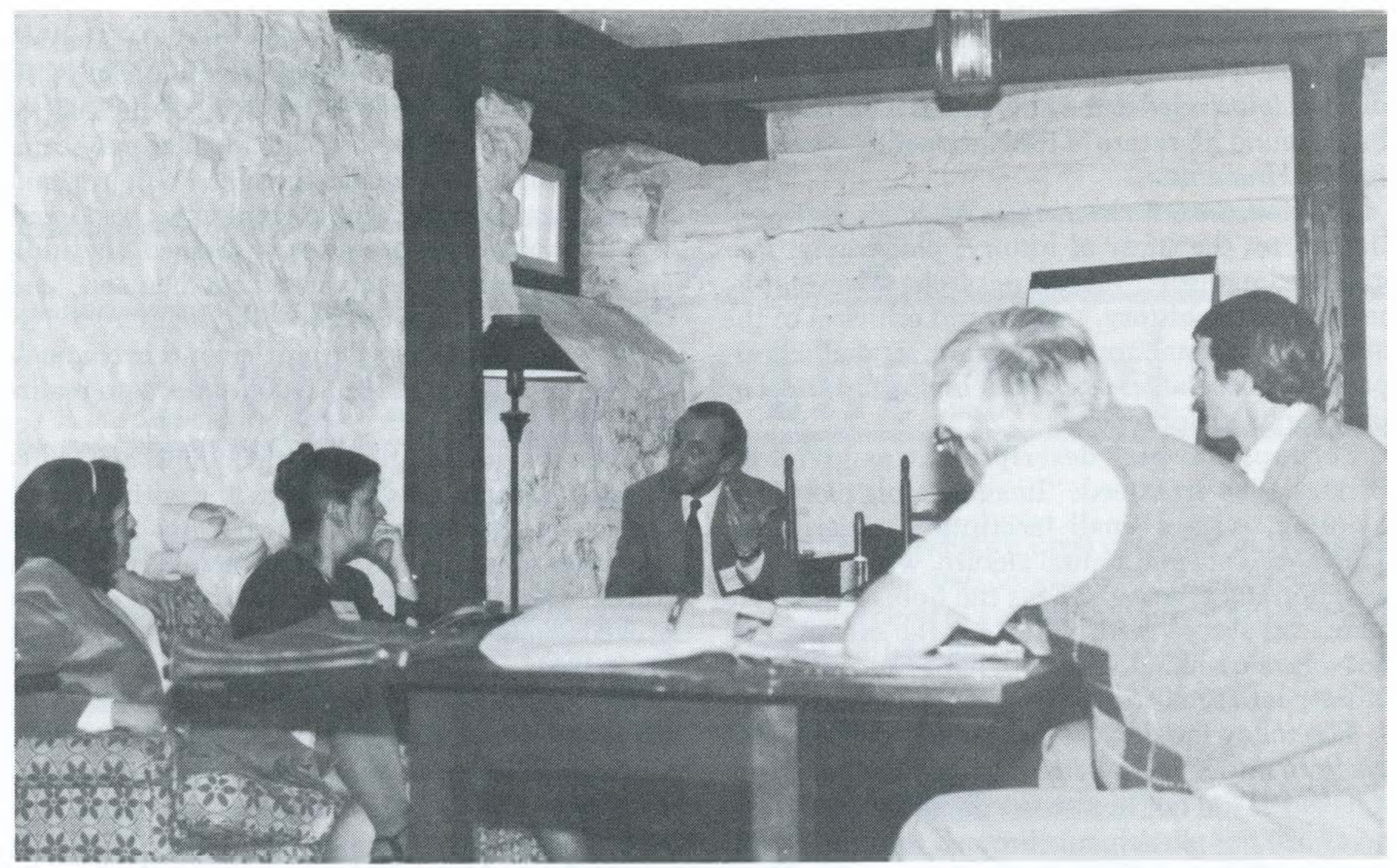

Tom Phelps, NEH program officer, advises a workshop team in Pleasant Hills, Ky.

\title{
Blue grass and NEH grants: An ACRL/PLA workshop in Kentucky
}

The peaceful Shaker village of Pleasant Hill, Kentucky, provided the setting for a recent NEH/ PLA/ACRL workshop, "Programming in the $\mathrm{Hu}$ manities." In the cool but sunny weather, half an hour away from Lexington, a total of 23 participants worked from breakfast until well into the night to learn how to request funding from the $\mathrm{Na}$ tional Endowment for the Humanities. The workshop, itself funded by a grant from NEH, was designed to aid public librarians, academic librarians, and humanists working in cooperation in the process of writing a proposal for a grant from NEH.

Groups came in teams of three (public, academic, and humanist) from as near as Louisville and Columbia, Kentucky, and as far away as Newport News, Virginia. Each group was to come equipped with some ideas for a project already in the planning stages; however, once arrived, the teams were paired and required to design an "exercise" program. The four resulting project proposals, though incomplete, proved to be of great interest to all participants and showed promise of success if they were to be submitted.

In order to set the participants on the correct humanistic path, Dr. Huel Perkins of Louisiana State University spoke on "What are the Humanities?" The humanities are not performance, they are not

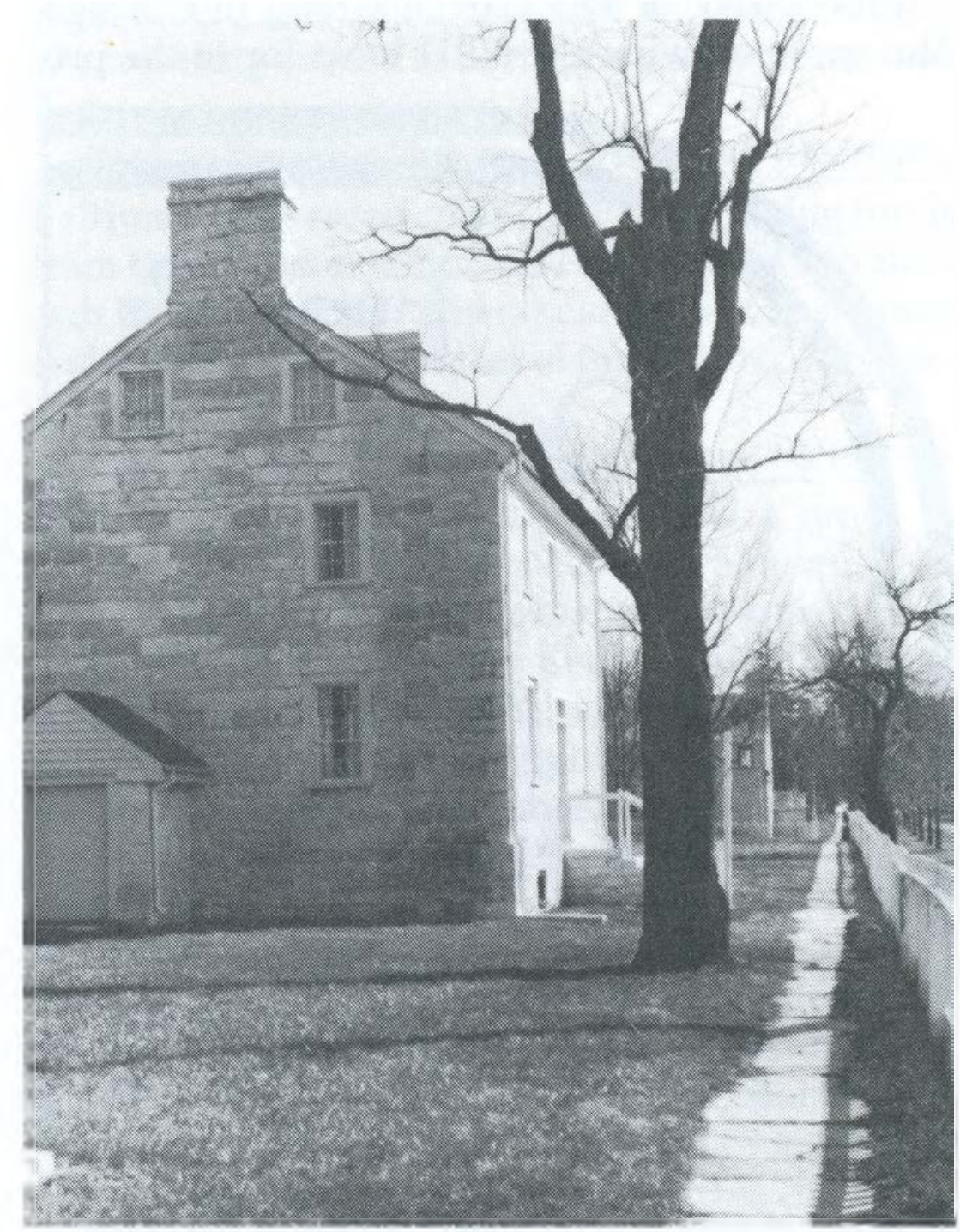

This former Shaker washing house now serves as lodging for visitors. 
exhibition, he said, but "the humanities are interpretation. They are about things." The description of what is included in the humanities is found in the background literature of the National Endowment for the Humanities:

"By law, the term humanities includes, but is not limited to, the study of history; philosophy; languages; linguistics; literature; archaeology; jurisprudence; the history, theory, and criticism of the arts; ethics; comparative religion; and those aspects of the social sciences that employ historical or philosophical approaches."

Perhaps the best description was given by Perkins as he explained: "Imagine a big picture, a painting, with a small inscription underneath. That's art. Imagine a small picture, with a large inscription underneath. That's the humanities." $\mathrm{He}$ ended his speech with praise for the creative endeavors of mankind, and with hope for continuing inquiry into such works.

The following day, with a clearer definition of the humanities and a better idea of how their pursuits did or did not fit into the discipline of the humanities, the participants listened to Tom Phelps explain, "Who is NEH?" Phelps, a program officer in the division of General Programs for NEH, described what types of programs the Endowment will support, and what types it will not. It would not want to provide funds for the mere performance of a musical, for example, but it might find a series of musicals, followed by a series of interpretative discussions, more fitting to the humanities. (This is, in fact, what one group planned to do.)

Julie Virgo, of The Carroll Group in Chicago, also spoke on what the NEH looks for in the pro-

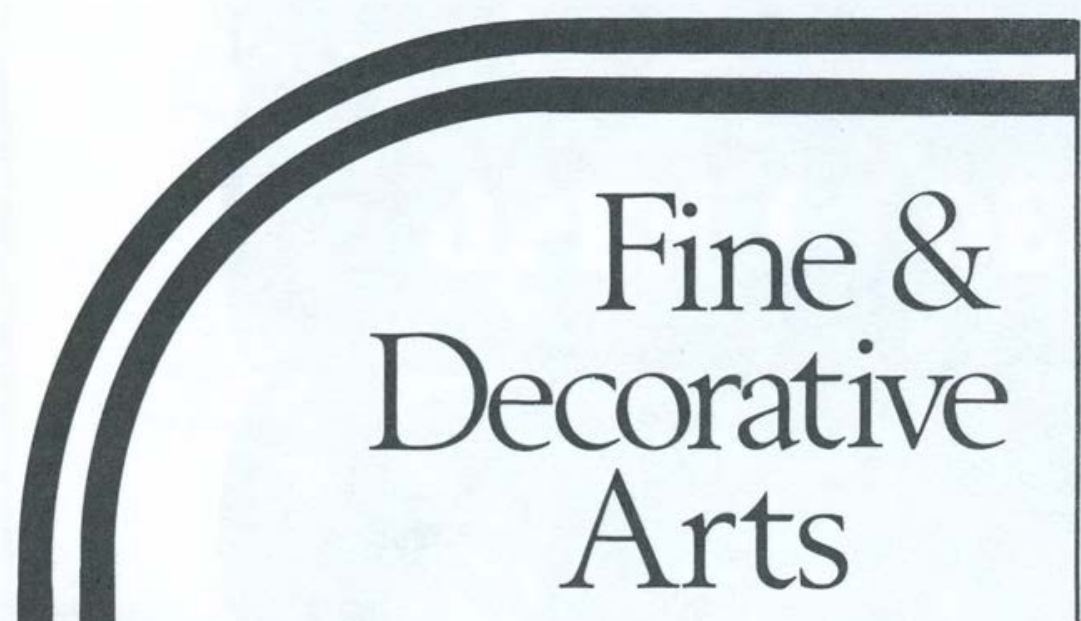

Eighty-two of the world's leading art research collections on microform are detailed in this 16-page, illustrated guide for art libraries.

\section{For a free guide, write, or call (212) 873-2100}

Clearwater Publishing Co., Inc. Box 1464

New York, N.Y. 10023 posals submitted. Herself a member of several review panels for such proposals, she spoke on the criteria for review: What is the value of the central idea behind the project? Will it advance public understanding of humanistic thought? Will it stimulate the use of the available humanities resources? Have the objectives been clearly defined, the audience designated, the management planned, and the budget carefully considered? Phelps' and Virgo's explanations aided the participants in channeling the wide variety of individual ideas into realizable projects.

Then the fun began when the groups, after having shared their objectives with the entire group, were paired in the hopes that two teams' respective proposals might be compatible enough to create a third "exercise" proposal. The variety of ideas proved to make the ensuing discussions lively, if not heated at times.

The next day when the exercise projects, written in the style and format of an actual NEH proposal, were presented, the fruits of the evening's discussions became evident. Four programs were presented, and the results were quite successful: one group planned to present a program on the Scandinavian culture of a particular neighborhood, with emphasis on the history and folklore; another planned a project of a series of American musicals linked with relevant discussions on their respective contexts; a third wanted to explore the issues surrounding modern medicine and the value of life by a series of readings, films and lectures; and the fourth group, "Newport Bend," composed of teams from Newport News, Virginia, and South Bend, Indiana, planned an ambitious eleven-week program of museum exhibits, readings, lectures, and discussions of its various ethnic communities.

Although the central themes of the programs differed, the form and practice of using the libraries as the focal point for research, lectures, and public gatherings for discussion were the same for each program. These project proposals, resulting from only one day of hard work, were very good beginnings, Phelps suggested, that he hoped would be submitted eventually to the $\mathrm{NEH}$ for funding.

No group left with a completed program proposal, but most left with a keener sense of the specifics of what they wanted to do, and what the $\mathrm{NEH}$ would support in general. Most striking, however, as the setting had promised from the very beginning, was the deepening of one's understanding of the humanities.

The history of one community's attempt at creating a more spiritual world surrounded us. There are now only a few Shakers left-none in Shakertown-yet their hopes for a better world continue in what they did create. The workshop answered many questions about the humanitieswhat they were, what they had to offer-and about how, given the cooperation of librarians with their knowledge of resources and academics with their grasp of subject disciplines, a good pro- 
gram could enrich a community, even one as small as the group in Shakertown.

For information on upcoming NEH workshops, contact Sandra Donnelly, ACRL, 50 E. Huron St., Chicago, IL 60611; (312) 944-6780._Donna Camloh, C\&RL News.

\section{4 Avulg fram the ffipld}

\section{Acquisitions}

-DePaul University Library, Chicago, has received a collection of more than 200 books on the Napoleonic Era. The books, collected by the late Dr. Max Thorek, were donated by his son Phillip. The collection includes materials describing the legal and political events of the early 19 th century.

- Duke University, Durham, North Carolina, has added four important first editions to its rare book collection. The earliest is the 1596 edition of Edmund Spenser's The Faerie Queene, published in two quarto volumes by William Ponsonbie. The other three are first editions of John Keats's Endymion (1818) and his first volume of poetry, called Poems (1817), and the first edition of Adonais (1821) by Percy Bysshe Shelley.

-The Toledo Museum of Art has received a collection of over 1,100 modern illustrated art books from Molly and Walter Bareiss. Highlights of the collection are more than 70 books illustrated by $\mathrm{Pa}-$ blo Picasso, Toulouse-Lautrec's Yvette Guilbert (1894) with sixteen lithographs of the Parisian singer accompanying the text by Gustave Geffroy, Pierre Bonnard's illustrations for Parallelement (1900) by Paul Verlaine, Wassily Kandinsky's Klange (1913) which contains his poetry and woodcuts, and Tristan Tzara's L'Antitete (1949) illustrated by Surrealist artists Max Ernst, Joan Miro, and Yves Tanguy. An exhibition featuring these and other works from the collection may be seen at the Museum September 22 through December 29, 1985.

-Williams College's Chapin Library, Williamstown, Massachusetts, has received collections of Eugene O'Neill and Robinson Jeffers assembled by Donald S. Klopfer, co-founder of Random House, who began publishing these authors in the early 1930s. The 20 O'Neill items include one of 12 special copies of Anna Christie with original artwork by Alexander King laid in, galley sheets for an abandoned 1947 edition of A Moon for the Misbegotten which was not published until 1952, and a typescript, early page proofs, and an inscribed first edition of Days without End showing a progression of major textual changes. Among the 23 Jeffers first editions are Grabhorn Press printings of Robinson Jeffers and the Sea, Solstice and Other Poems, Return, and Poems of 1928 with a signed Ansel Adams portrait of the poet.

\section{Grants}

- Georgia State University's Southern Labor Archives, Atlanta, has been awarded a $\$ 10,000$ grant by the Georgia Endowment for the Humanities and the National Endowment for the Humanities to explore the history of textile workers in Atlanta's Cabbagetown and the Celanese Textile Community in Rome, Georgia. The project will involve research, oral history interviews, exhibits, and a series of public programs to be held in each community. Photographs, artifacts, and documents portraying housing, working conditions, child labor, and union activities will become part of a traveling exhibit to be displayed in Atlanta and Rome.

-Johns Hopkins University's Peabody Institute, Baltimore, has received $\$ 27,619$ in matching funds from the National Historical Publications and Records Commission for a two-year project to arrange and describe 760 linear feet of institute records dating from 1857 to 1977.

- The Moravian Music Foundation, WinstonSalem, North Carolina, has received a grant of $\$ 25,200$ from the Winston-Salem Foundation to undertake corrective conservation measures in its archival collections of manuscript music. The music collections contain not only the sacred choral compositions of Moravian composers but also numerous works by European composers of the 18th and early 19th centuries. The latter, hand-copied by Moravian minister-musicians, are by such composers as Haydn, Stamitz, Danzi, Beethoven, the sons of J.S. Bach, and Handel. Several sinfonias by Johann Christian Friedrich Bach, flute duets by Kleinknecht, and string quartets by Stamitz are among the unique copies. The Foundation will undertake a three-year project to preserve the material and has employed Timothy D. Pyatt as conservator to implement the program.

- Northwestern University's Herskovits Library 